\title{
PENINGKATAN KEAKTIFAN SISWA DALAM PERMAINAN FUTSAL MELALUIMETODETGT PADA SISWA KELAS X DI SMA SELAMAT PAGI INDONESIA KOTA BATU
}

\author{
Pandu Adi Wibowo ${ }^{1)}$ \\ Pendidikan Jasmani Kesehatan dan Rekeasi \\ Fakultas Pendidikan Ilmu Eksakta dan Keolahragaan \\ IKIP Budi Utomo Malang \\ Email:1pndwbw@yahoo.co.id
}

\begin{abstract}
ABSTRAK
Pendidikan jasmani sebagai bagian integral dari pendidikan dari sistem pendidikan secara keseluruhan. Pendidikan jasmani harus diarahkan pada pencapaian tujuan pendidikan tersebut. Tujuan pendidikan jasmani bukan aktivitas jasmani, tetapi bagaimana mengembangkan seluruh potensi siswa melalui aktivitas jasmani. Penelitian ini menggunakan penelitian tindakan kelas. Penelitian ini bertujuan untuk meningkatkan keaktifan siswa melalui metode TGT dalam permainan futsal. Subjek penelitian adalah siswa Kelas X SMA Selamat Pagi Indonesia Kota Batu yang terdiri dari25orang siswa. Dalam pelaksanaan TGT pembagian kelompok dilakukan dengan dua cara: cara pertama kelompok berdasarkan gender, cara kedua kelompok dicampur antara putra dan putri. Penelitian ini telah dilaksanakan dalam dua siklus. Siklus pertama menunjukkan bahwa aspek afektif tentang keaktifan masih diperlukan perbaikan, sehingga perlu dilakukan perbaikan pada siklus 2. Pada siklus 2 sudah menunjukkan hasil yang optimal sehinggatidak diperlukan lagi siklus berikutnya. Karena pada siklus 2 sudah meningkat. Dari hasil penelitian menunjukkan bahwa metode TGT dapatmeningkatkan keaktifan siswa SMA Selamat Pagi Indonesia Kota Batu. Meningkatnya keaktifan siswa juga akan mempengaruhi pola belajar siswa dalam mencapai tujuan baik secara kognitif, afektif maupun psikomotor.
\end{abstract}

Kata kunci: Keaktifan, Futsal, TGT

\begin{abstract}
Physical education as an integral part of the education of the education system as a whole. Physical education should be directed to the attainment of the educational goals. The purpose of physical education is not physical activity, but how to develop all potential students through physical activity. This study uses classroom action research. This study aims to improve student activeness through TGT method in futsal game. The subjects of the study were students of Class X SMA Selamat Pagi Indonesia Kota Batu consisting of 25 students. In the implementation of the TGT the division of the group was conducted in two ways: the first way groups were based on gender, the way the two groups were mixed between sons and daughters. This study has been carried out in two cycles. The first cycle shows that the affective aspect of activeness is still needed improvement, so it needs to be done in cycle 2. In cycle 2 has shown optimal result so no longer needed next cycle. Because in cycle 2 has increased. From
\end{abstract}

Pandu Adi Wibowo. Peningkatan Keaktifan Siswa dalam Permaian Futsal Melalui Metode TGT pada Siswa Kelas X di SMA Selamat Pagi Indonesia Kota Batu 
result of research indicate that TGT method can increase activity of SMA Pagi Indonesia High School student of Batu. Increased activity of students will also affect the learning patterns of students in achieving goals both cognitively, affectively and psychomotor.

Keywords: Activity, Futsal, TG

\section{PENDAHULUAN}

Istilah "Pendidikan" merupakan kata yang tidak asing lagi untuk hampir setiap orang. Namun demikian, istilah ini lebih sering diartikan secara berbeda dari masa ke masa. Mata pelajaran pendidikan jasmani merupakan salah satu mata pelajaran di Sekolah Menengah Atas.Pendidikan jasmani menjadi penting karena dijadikan dasar bagi anak untuk mengaplikasikan gerak.Pendidikan jasmani merupakan penyeimbang dalam pembelajaran baik itu aspek kognitif, afektif dan psikomotor.Dengan harapankeseimbangan dari ketiga aspek diperlukan. Keberhasilan siswa di Sekolahsangat ditentukan oleh kreatifitas guru dalam menerapkan metode dalam mengajar. Penerapan metode pembelajaran yang kurang tepat sangat berpengaruh pada hasil pembelajaran.

Guru pendidikan jasmani adalah guru yang selalu dinanti kehadirannya oleh siswa. Guru pendidikan jasmani dianggap guru yang paling menyenangkan, karena identik dengan mata pelajaran bermain. Untuk itu bagaimana guru dapat memberikan pelayanan yang baik terhadap siswa. Guru dapat mendesain pembelajaran dengan menarik dan menyenangkan, maka dari itu guru pendidikan jasmani dituntut untuk dapat mengembangkan metode pembelajaran yang sesuai dengan materi yang diajarkan.

Materi futsalmerupakan salah satu materi permainan bola besar yang terdapat pada jenjang SMA. Futsaladalah permainan yang dilakukan oleh dua regu dimana masing masing terdiri 5 orang anggota.Teknik permainan futsal seperti: passing, shooting dan dribbling merupakan sebagian teknik dasar yang harus dikuasai oleh pemain. Sebagian anak mungkin senang melakukan permainan, tetapi mungkin juga ada sebagian anak tidak menyukai permainanfutsal. Untuk itu guru dituntut untuk selalu kreatif dalam setiap permasalahan dalam pembelajaran.

Pengalaman peneliti sebagai guru Pendidikan Jasmani selama ini menunjukkan bahwa masih banyak siswa kurang aktif dalam permainan futsal, utamanya siswa perempuan.Keaktifan dalam belajar

Pandu Adi Wibowo. Peningkatan Keaktifan Siswa dalam Permaian Futsal Melalui Metode TGT pada Siswa Kelas X di SMA Selamat Pagi Indonesia Kota Batu

$P$ a g e $\mid 15$ 
menjadi prioritas utama dalam keberhasilan belajar. Menurut pandangan ilmu jiwa modern dalam Sardiman (2011) menerjemahkan jiwa manusia sebagai sesuatu yang dinamis, memiliki potensi dan energi sendiri. Artinya nilai aktif terkait dengan potensi yang dimiliki oleh manusia. Berdasarkan penelitian ini indikator keaktifan yang dimaksud adalah yaitu kerjasama, sportifitas, memanfaatkan potensi teman, membuat strategi, dan saling membantu. Hasil belajar siswa SMA dalam materi gerak dasar permainan futsalsemester 1/2016-2017 masih rendah, terbukti, hasil observasi awal menunjukkan bahwa kerjasama siswa masih $25 \%$, sportifitas $20 \%$, membuat strategi $15 \%$, memanfaatkan potensi teman $15 \%$, dan saling membantu $10 \%$. Kemudian keterampilan siswa dalam dribel 20\%, passing $20 \%$, shooting $20 \%$. Kondisi demikian apabila dibiarkan akan mempengaruhi pencapaian prestasi belajar siswa.Hal tersebut menunjukkan adanya permasalahan yang harus dicari jalan keluarnya. Oleh karena itu, perlu dilakukan tindakan yang dilaksanakan secara kolaboratifuntuk meningkatkan keaktifan siswa.

Tindakan yang dilakukan dalam penelitian ini dalam upaya meningkatkan keaktifan siswa dalam permainan futsal melalui metode team game tournamentkelas X SMA. Penggunaan metode team game tournament adalah untuk mengatasi rendahnya rasa jenuh dan malas pada siswa sehingga lebih aktif dalam permainan futsal.Sesuai dengan yang disampaikan Sutikno (2007) yaitu menggunakan metode pembelajaran yang bervariasi. Artinya metode yang digunakan guru haruslah bervariasi.Selaras dengan Chotimah (2010) bahwa aktivitas belajar dengan permainan yang dirancang dalam pembelajaran kooperatif tipe TGT memungkinkan siswa belajar dalam kondisi yang lebih rileks sehingga siswa tidak merasa bosan. Artinya siswa apabila dalam belajar tidak bisa secara monoton, siswa lebih senang dan bersemangat jika memiliki tantangan da suasana belajar yang berbeda.

Sejalan dengan Khohar (2007) bahwa Penerapan Pembelajaran Kooperatif Model Team Game Tournament pada permainan futsal dalam mata pelajaran Pendidikan Jasmani Olahraga dan Kesehatan pada Siswa Kelas IX G SMP Negeri 2 Gubug Semester 2 Tahun Pelajaran 2007/2008 adalah meningkat.Sama halnya dengan penelitian Nursaori (2014) Pengaruh Model Pembelajaran Kooperatif Tipe TGT (TeamGames Tournament) terhadap hasil belajar siswa Layup-shoot dalam Permainan Bola Basket juga meningkat.

Artikel ini mendeskripsikan hasil penelitian bahwapenelitian tindakan kelas tentang keaktifan siswa dalam bermainfutsal melalui 
metode team game tournament siswa kelas X di SMA Selamat Pagi Indonesia Kota Batu yang telah dilaksanakan 2 siklus yaitu meningkat.

\section{METODE}

Penelitian ini merupakan penelitian kualitatif, dengan teknik pelaksanaan penelitian tindakan kelas (classroom Action Research). Wibawa (2003) mengemukakan bahwa penelitian tindakan kelas adalah suatu penelitian yang dilakukan secara sistematis reflektif terhadap berbagai "aksi" atau tindakan yang dilakukan oleh guru, mulai dari perencanaan sampai dengan penilaian terhadap tindakan nyata didalam kelas yang berupa kegiatan belajar mengajar untuk memperbaiki kondisi pembelajaran yang dilakukan. Penelitian tindakan ini digunakan untuk memperbaiki pembelajaranfutsal bagisiswa-siswi di SMA Selamat Pagi Indonesia Kota Batu. Waktu penelitian bulan Agustus 2016 sampai bulan Oktober 2016 dan dilaksanakan saat jam pelajaranpendidikan jasmani dan olahraga selama $4 \mathrm{x}$ pertemuan. Ruang lingkup penelitian ini adalah materi pembelajaran Permainan Futsalsepertiyang terdapat didalam standar isi khususnya pada permainan futsal.Subjek yang digunakan pada penilitianini adalah peserta didik kelas X SMA Selamat Pagi Indonesia Kota BatuTahun Pelajaran2016/2017 dengan jumlah peserta didik sebanyak25 anak. Fokus penelitian adalah keaktifan siswa dalam permainan futsaldengan tetap memperhatikan aspek psikomotor gerak dasar futsal dan aspek kognitif tentang pengetahuan bermain.

Instrumen penelitian yang digunakan berupa; (1) instrumen pembelajaran, yaitu berupa rencana pelaksanaan pembelajaran; (2) instrumen evaluasi, yaitu berupa tes keterampilan bermain futsal, dan (3) instrumen observasi, yaitu berupa skala penilaian yang akan diisi oleh pengamat dan peneliti pada saat mengadakan proses pembelajaran yang berhubungan dengan aktivitas belajar peserta didik.

Prosedur tindakan penelitian dirancang sesuai rancangan penelitian tindakan kelas. Kegiatan diterapkan dalam upaya untuk meningkatkan hasil belajar permainan futsal dan keaktifan peserta didik dalam pembelajaran penjas. Tahapan penelitian disusun dalam siklus penelitian. Setiap siklus memiliki 4 tahapan, yaitu (1) perencanaan, (2) tindakan, (3) pengamatan, dan (4) refleksi. 


\section{HASIL DAN PEMBAHASAN \\ Siklus I \\ Perencanaan}

Dalam standar kompetensi disebutkan tentang mempraktikkan gerak dasar ke dalam aktivitas jasmani dan nilai yang terkandung di dalamnya. Kompetensi dasar mempraktikkan gerak dasar menendang obyek berbagai ukuran dalam permainan sederhana, dan kerjasama, toleransi, kejujuran dan tanggung jawab. Indikator yang dikembangkan dalam penelitian ini terdiri dari indikator psikomotor, indikator afektif, dan indikator kognitif. Indikator psikomotor yang harus dikuasai siswa adalah keterampilan shooting, dribel dan passingbola dengan baik, dapat bermain futsal. Untuk indikator afektif ditunjukan oleh keaktifan saat bermain futsal. Pada bagian indikator kognitif yaitu dapat menyebutkan teknik dasar dalam permainan futsal.

Melalui perencanaan tersebut dilakukan peningkatan dengan metode TGT. Perencanaan yang dilakukan dengan mengelompokkan siswa-siswi dengan beranggotakan 5 orang. Beberapa kelompok terdiri dari kelompok putra dan kelompok putri akan bermain. Dari beberapa kelompok bertanding putri lawan putri, putra lawan putra. Bagi kelompok yang belum bertanding disarankan untuk menjadi supporter.

Pedoman observasi disusun atas dasar aspek kerjasama, sportifitas, strategi, dan pemanfaatan potensi teman di lapangan. Sedangkan metode TGT yang menjadi bahan observasi yaitu presentasi kelas, sebagai fasilitator, melaksanakan permainan, membagi kelompok dan memberikan penghargaan.Dalam lembar observasi keterampilan akan dilakukan observasi tentang cara shooting, dribble dan passing, serta observasi tentang wawancara yaitu hasil kognitif siswa.

\section{Pelaksanaan}

Pada kegiatan awal pembelajaran, siswaduduk berkumpul di tengah lapangan, dilakukan pengecekan kehadiran siswa, melakukan gerakan pemanasan menendang bola. Pemanasan menendangdilakukan gerakanmenendang bola melambung berpasangan, melakukan gerakan menendang bola menyamping berpasangan atau berkelompok, melakukan gerakan menendang bola mendatar berpasangan, Kegiatan awal dalam bentuk pemanasan dilaksanakan kurang lebih 10 menit.

Pada kegiatan inti dilakukan kegiatan bermain futsal. Masingmasing kelompok dibagi kelompok-kelompok yang terdiri dari 5 orang. Masing-masing kelompok terdiri dari kelompok putra dan kelompok putri. Kelompok putra bertanding kelompok putra dan kelompok putri

Pandu Adi Wibowo. Peningkatan Keaktifan Siswa dalam Permaian Futsal Melalui Metode TGT pada Siswa Kelas X di SMA Selamat Pagi Indonesia Kota Batu 
bertanding dengan kelompok putri. Dengan menggunakan pertandingan kalah menang.Kegiatan inti diakhiri kurang lebih 40 menit, yaitu setelah semua kelompok melakukan pertandingan.

\section{Pengamatan}

Pengamatan dilakukan oleh observer yaitu teman sejawat sebanyak 2 orang.Kegiatan pengamatan difokuskan padaaspek afektif, psikomotor dan kognitif. Berdasarkan pengamatan observer saat di lapangan secara umum disimpulkan bahwa pembelajaran permainan futsal dilakukan dengan baik. Siswa antusias melakukan kegiatan. Hanya saja dari sebagian siswa masih ada yang belum menunjukkan sikap kerjasama, sportifitas, memanfaatkan potensi teman, membuat strategi, dan saling membantu.

Pembelajaran yang dilakukan dinilai observer sudah aktif. Siswa sudah antusias dalam mengikuti. Siswa mengikuti pembelajaran dengan semangat. Aktif yang dimaksud adalah aktif secara fisik. Keaktifan yang diharapkan padasiswa adalah sejauh mana siswa dan siswi mau bekerjasama, bertindak sportif, mampu membuat strategi, mampu memanfaatkan potensi teman serta mereka saling membantu antar anggota dalam tim.

Berdasarkan rekapitulasi data keaktifan siswa yang dilakukan oleh observer adalah sebagai berikut. Sikap kerjasama 50\%, sikap sportifitas siswa yaitu $60 \%$, aspek memanfaatkan potensi siswa yaitu $70 \%$, aspek membuat strategi yaitu $30 \%$, saling membantu yaitu $80 \%$. Kemudian ketrampilan siswa yaitu shooting $30 \%$, passing yaitu $50 \%$ se dan dribel $20 \%$. berdasarkan hasil wawancara tentang aspek kognitif baru $50 \%$ yang bisa menjawab.

\section{Refleksi}

Berdasarkan analisis data hasil tindakan pada siklus I disimpulkan hasil sebagai berikut. Pelaksanaanmetode TGT dalam pembelajaran permainan futsalbelum menunjukkan hasil yang optimal. Hal ini ditunjukkan oleh capaian skor kerjasama, memanfaatkan potensi siswa, membuat strategi, keterampilan shooting, passing, dan driblle yang masih rendah. Walaupun untuk sportifitas dan saling membantu sudah tinggi. Peningkatan keaktifan siswa dalam permainan futsal dapat dilihat dengan membandingkan keaktifangerak siswa sebelum dan sesudah menggunakan metode TGT. Berdasarkan uraian di atas maka perlu dilakukan siklus berikutnya untuk 
memperbaiki kinerja pembelajaran. Khususnya hal-hal yang dirasakan masih dalam capaian rendah.

\section{Siklus 2}

\section{Perencanaan}

Siswa membentuk lingkaran, mengecek kehadiran siswa, melakukan gerakan pemanasan menggunakan lempar dan tangkap bola. Pada siklus II dilakukan sedikit berbeda dengan siklus Iyaitu dengan menggunakan sistem pertandingan akan dibagi putra dan putri digabung menjadi satu kelompok. Masing-masing kelompok terdiri dari 5 orang terdiri putra dan putri. Semua kelompok bermain futsal dengan menggunakan sistem pertandingan.

Melalui perencanaan tersebut dilakukan tindakan dengan metode TGT. Pertemuan pertama pertandingan yang digunakan menggunakan sistem babak penyisihan, pertemuan kedua menggunakan babak semi final dan pertemuan ketiga menggunakan babak final. Dari beberapa kelompok akan bertanding. Bagi kelompok yang belum bertanding disarankan untuk menjadi supporter.

Pedoman observasi disusun atas dasar bentuk kerjasama, sportifitas, strategi, dan pemanfaatan potensi teman di lapangan. Sedangkan metode TGT yang menjadi bahan observasi yaitu presentasi kelas, sebagai fasilitator, melaksanakan permainan, membagi kelompok dan memberikan penghargaan. Dalam lembar observasi keterampilan akan dilakukan observasi tentang cara shooting, dribble dan passing. Tanya jawab tentang hasil kognitif siswa.

\section{Pelaksanaan}

Pada kegiatan awal pembelajaran, siswa duduk berkumpul di tengah lapangan, dilakukan pengecekan kehadiran siswa, melakukan gerakan pemanasan lempar tangkap bola. Pemanasan sisawadilakukan gerakanmenendang bola melambung berpasangan, melakukan gerakan menendang bola menyamping berpasangan atau berkelompok, melakukan gerakan menendang bola mendatar berpasangan, Kegiatan awal dalam bentuk pemanasan dilaksanakan kurang lebih 10 menit.

Pada kegiatan inti dilakukan kegiatan bermain futsal. Masingmasing kelompok dibagi kelompok-kelompok yang terdiri dari 5 orang. Masing-masing kelompok terdiri dari siswa putra dan siswa putri (digabung). Masing-masingkelompok. Dengan menggunakan pertandingan kalah menang. Kegiatan inti diakhiri kurang lebih 40 
menit, yaitu setelah semua kelompok melakukan pertandingan. Setelah selesai dilakukan tanya jawab tentang materi yang telah disampaikan.

\section{Pengamatan}

Pengamatan dilakukan oleh observer yaitu teman sejawat sebanyak 2 orang.Kegiatan pengamatan difokuskan padaaspek afektif, psikomotor dan kognitif. Berdasarkan pengamatan observer saat di lapangan secara umum disimpulkan bahwa pembelajaran permainan futsal dilakukan dengan baik. Siswa antusias melakukan kegiatan. Hanya saja dari sebagian siswa masih ada yang belum menunjukkan sikap kerjasama, sportifitas, memanfaatkan potensi teman, membuat strategi, dan saling membantu.

Pembelajaran yang dilakukan dinilai observer sudah meningkat. Siswa sudah antusias dalam mengikuti. Siswa mengikuti pembelajaran dengan semangat. Aktif yang dimaksud adalah aktif secara fisik. Keaktifan yang diharapkan pada siswa adalah sejauh mana siswa dan siswi mau bekerjasama, bertindak sportif, mampu membuat strategi, mampu memanfaatkan potensi teman serta mereka saling membantu antar anggota dalam tim.

Berdasarkan rekapitulasi data keaktifan siswa yang dilakukan oleh observer adalah sebagai berikut. Sikap kerjasama $80 \%$, sikap sportifitas siswa yaitu $90 \%$, aspek memanfaatkan potensi siswa yaitu $80 \%$, aspek membuat strategi yaitu $60 \%$, saling membantu yaitu $90 \%$. Kemudian ketrampilan siswa yaitu shooting $20 \%$, passing yaitu $90 \%$ dan dribel 30\%. Berdasarkan hasil tanya jawab sudah $60 \%$ mengalami peningkatan.

\section{Refleksi}

Berdasarkan analisis data hasil tindakan pada siklus II disimpulkan hasil sebagai berikut. Pelaksanaanmetode TGT dalam pembelajaran permainan futsalsudah menunjukkan hasil yang optimal. Hal ini ditunjukkan oleh capaian skor kerjasama, memanfaatkan potensi siswa, membuat strategi, keterampilan shooting, passing, dan driblle yang sudah meningkat. Aspek-aspek dalam permainan futsal dapat dilihat dengan membandingkan keaktifansiswa sebelum dan sesudah menggunakan metode TGT. Berdasarkan uraian di atas maka tidak perlu dilakukan siklus berikutnya. 


\section{KESIMPULAN}

Berdasarkan hasil simpulan di atas diketahui bahwa metode TGT yang digunakan sebagai tindakan untuk meningkatkan keaktifan siswa dalam permainan futsal telah berdampak positif. Dengan metode TGT, peserta didik lebih aktif dalam mengikuti kegiatan pembelajaran. Peserta didik melakukan kegiatan secara berkompetisi menjadikan keaktifan peserta didik meningkat. Disamping itu metode TGT dengan adanya reward akan menjadikan proses pembelajaran lebih bermakna. Dengan diberikan reward, guru dapat mengamati peserta didik secara langsung untuk mengetahui mencapai tujuan pembelajaran, serta peserta didik diberi keleluasaan untuk bermain sehingga akan lebih aktif, kreatif dan menyenangkan dalam proses pembelajaran.

\section{Saran}

Hasil penelitian ini dapat digunakan untuk acuan bagi peneliti lain yang akan mengadakan penelitian sejenis lebih lanjut. Penelitian ini juga dapat menjadi sumbangan pemikiran bagi guru untuk mengembangkan variasi strategi pembelajaran dalam mengajar pendidikan jasmani.

1. Metode TGT dalam permainan futsal sudah sering dilakukan dalam pertandingan-pertandingan antar lembaga maupun antar klub, sehingga metode ini dapat dilakukan oleh guru dalam pembelajaran secara berkualitas dan menyenangkan.

2. Tidak hanya dalam permainan futsal, metode TGT dapat pula dilakukan dalam materi yang lain.

3. Metode TGT merupakan metode yang akan memberikan inspirasi untuk guru dalam menyelenggarakan pembelajaran yang inovatif dan keratif.

\section{DAFTAR PUSTAKA}

Chotimah. 2010. Metode Pembelajaran untuk Penelitian Tindakan Kelas.Bandung: Rineka Cipta.

Khohar, Abdul. 2007. Penerapan Pembelajaran Kooperatif Model Team Game Tournament pada Permainan Futsaldalam Mata Pelajaran Pendidikan Jasmani Olahraga dan Kesehatan pada Siswa Kelas IX G SMP Negeri 2 Gubug Semester 2 Tahun Pelajaran 2007/2008. PPS Pendidikan Olahraga. Universitas Negeri Semarang. 
Nursaori, Ferdianka. 2014. Pengaruh Model Pembelajaran Kooperatif Tipe TGT (Teamgame Tournamen) Terhadap Hasil Belajar Lay Up Shoot dalam Permainan Futsal Pendidikan Jasmani Kesehatan dan Rekreasi Fakultas Pendidikan Olahraga dan Kesehatan. UPI: Bandung.

Pidarta, Made. 2012. AnalisaData Penelitian-Penelitian Kualitatif dan Artikel. Surabaya: Unesa University Press.

Sardiman. M.A. 2011. Interaksi dan Motivasi Belajar Mengajar. Jakarta: PT Raja Grafindo Persada.

Sutikno,S.2007.PeranPenelitidalamMembangkitkanMotivasiBelajarSis wa.(On Line)http://jurnal-online.um.ac.id. Diakses 28 April 2016. 